Громченко Валерій Васильович, кандидат мистецтвознавства, доиент, проректор з наукової роботи Дніпропетровської академії музики ім. М. Глінки

тел. (097) 470 - 23 - 10 e-mail: gromchencko.valeriy@gmail.com

\title{
ДУХОВЕ СОЛО В МУЗИЦІ РОМАНТИЗМУ
}

Метою статті $\epsilon$ визначення ряду причин, мотивів щодо наслідків зменшення концертно-творчої активності, мистецького функціонування духового соло у сфері академічного інструментального виконавства часів музичного романтизму. Методологія розробки проблеми складається 3 низки теоретичного та емпіричного науково-дослідного інструментарію. Історичний метод дозволяє виділити конкретний культурно-історичний період для вивчення означеного питання. Опрацювання та усвідомлення характерних складових духового соло здійснюється на основі використання системно-комплексного методу. Практичні висновки дослідження грунтуються на використанні методу узагальнення. Ціннісний фактор добору композицій духового соло, як музичного матеріалу пропонованого дослідження, стверджує використання в означеній науковій статті аксіологічного підходу. Наукова новизна роботи зумовлюється зверненням автора до найменш досліджуваного явища в духовому академічному музичновиконавському мистецтві, а саме феномену сценічно-одноосібної художньої духової практики соло у період музичного романтизму. Висновки. Духове соло у часи музичного романтизму характеризується вагомим зменшенням творчої активності. Серед максимально значимих мотивів, причин вище окресленого мистецького становища відзначимо наближення духового соло до аматорського музикування, активізацію процесів опанування технікою гри на духових академічних інструментах серед представників когорти музикантів-аматорів, суттєве конструкційне відставання духового інструментарію від інших представників 
сфери професійного інструментального музикування, зокрема струнно-смичкових інструментів та, безперечно, фортепіано, а також стрімке еволюціонування ансамблево-оркестрового виконавства, в якому духові академічні інструменти мали першорядне художнє, естетико-оновлююче значення.

Ключові слова: духове соло, композитор, виконавець, музичний романтизм, сценічно-одноосібне виконавство, твір, інструментальна академічна музика, ансамблево-оркестрова творчість.

Громченко Валерий Васильевич, кандидат искусствоведения, доцент, проректор по научной работе Днепропетровской академии музыки им. М. Глинки

\section{Духовое соло в музыке романтизма}

Целью статьи является определение ряда причин, мотивов относительно последствий уменьшения концертно-творческой активности, функционирования духового соло в сфере академического инструментального исполнительства периода музыкального романтизма. Методология разработки проблемы состоит из ряда теоретического и эмпирического научноисследовательского инструментария. Исторический метод позволяет выделить конкретный культурно-исторический период для изучения обозначенного вопроса. Обработка и осознание характерных составляющих духового соло осуществляется на основе использования системно-комплексного метода. Практические выводы исследования базируются на использовании метода обобщения. Ценностный фактор подбора композиций духового соло, как музыкального материала предлагаемого исследования, утверждает использование в представленной научной статье аксиологического подхода. Научная новизна работы обуславливается обращением автора к наименее исследованному явлению в духовом академическом музыкальноисполнительском искусстве, а именно феномену сценичноиндивидуальной художественной духовой практики соло в период музыкального романтизма. Выводы. Духовое соло в часы музыкального романтизма характеризуется существенным уменьшением творческой активности. Среди максимально значимых мотивов, причин выше очерченного культурно- 
творческого положения выделим направленность духового соло к любительскому исполнительству, активизацию процессов овладения техникой игры на духовых академических инструментах исполнителями круга музыкантов-любителей, существенное конструкционное отставание духового инструментария от других представителей сферы профессиональной инструментальной практики, а именно струнно-смычковых инструментов и, бесспорно, фортепиано, а также стремительную эволюцию ансамблево-оркестрового исполнительства, в котором духовые академические инструменты имели первостепенное художественное, эстетико-обновляющее значение.

Ключевые слова: духовое соло, композитор, исполнитель, музыкальный романтизм, сценически-индивидуальное исполнительство, произведение, инструментальная академическая музыка, ансамблево-оркестровое творчество.

Hromchenko Valerii, candidate of Arts, docent, vice rector of research for Mikhail Glinka academy music of Dnepropetrovsk region

\section{Wind instrument solo in the music of Romanticism}

The purpose of this article is determining the series reasons, motives concerning results decreasing of concert-creative activity, artistic functioning of wind instrument solo in the sphere of academic instrumental performing at the time of musical romanticism. Methodology developing of the problem consists of the range theoretic and empirical scientifically researching instruments. The concrete culturally historical period for studying denoted question is delineated by historical method. The handing and awareness characteristic segments of wind instruments solo is realized by basement applying of system-complex method. Practical conclusions of the investigation are founded by using the method of generalization. Employment into represented scientific article of the axiological approaching is approved by evaluative factor of the choosing for compositions wind instrument solo as musical material of the proposing investigation. Scientific newness of this researching is conditioned the appealing of the author to least explored phenomenon in the wind academic musically performing art exactly the appearance of scenically individual artistic wind instrument practice solo at the period musical romanticism. Conclusions. Wind instrument solo is characterized essential decreasing 
creative activity in the time musical romanticism. Among maximal significant motives, reasons respecting above mentioned culture-creative situation we are outlining the next positions. There is directionality wind instrument solo to amateur performing, intensification of the processes mastering of technic playing on wind academic instruments by performers of musicians-amateurs' group, considerable constructive the lag behind of wind instruments from other celebrated representatives for the sphere of professional instrumental practice a namely stringed bow instruments and, certainly, fortepiano, as well as impetuous evolution of ensemble orchestra performing, in which the wind academic instruments possessed the primary and amazing important artistic, aestheticcorrecting significance.

The key words: wind instrument solo, composer, performer, musical romanticism, stage individual performing, composition, instrumental academic music, ensemble orchestra creation.

Постановка проблеми. Зростаюча динаміка художнього сценічно-одноосібного виконавства на духових академічних інструментах у XX - початку XXI століттях постає цілком закономірним явищем, після майже повсякчасного ансамблевооркестрового використання духових інструментів у XIX сторіччі. Та все ж таки неможна однозначно стверджувати відсутність довершених одноосібних композицій духового соло у творчості митців-романтиків (як композиторів, так i виконавців), адже, наголосимо, неможливо заперечити вагомий вплив на всю тогочасну інструментальну академічну музику скрипкових шедеврів соло, наприклад, надзвичайно відомих 24 каприсів для скрипки соло Н. Паганіні тощо.

Нечисленні зразки духової художньо-індивідуальної творчості у часи романтизму (Рондо-капричіозо для флейти соло А. Стаміца, Каприси для флейти соло Т. Бьома та ін.) ставлять питання як про виявлення їх специфіки (композиторська та виконавська своєрідність), так і стверджують необхідність окреслення самобутності означеного культурно-історичного періоду в аспекті еволюціонування духового виконавства соло.

Таким чином, у лоні сучасної науково-дослідницької думки, насамперед, сфери духового академічного музично-виконавського мистецтва, постає проблема дослідження причин послаблення 
творчої активності сценічно-індивідуальної духової практики у проміжок часу між шедеврами Й.С. Баха (Партита a-moll для флейти соло), Г.Ф. Телемана (12 Фантазій для флейти соло) та одноосібними духовими композиціями авторів ХX століття К. Дебюссі („Сірінкс” для флейти соло), І. Стравінського (Три п’єси для кларнета соло), Б. Бріттена („Шість метаморфоз за Овідієм” для гобоя соло) та ін.

Відтак, саме часи музичного романтизму, 3 масштабним ствердженням оновленої естетики ансамблево-оркестрового виконавства, постають проблемним, найбільш дискусійним та водночас найменш дослідженим періодом у панорамі еволюціонування духового академічного сценічно-одноосібного виконавства соло.

Актуальність означеної проблеми зумовлюється насамперед ii практичним значенням, окресленим як композиторською, виконавською, так i педагогічною сферами застосування індивідуальної духової практики. Адже стрімка концертно-творча активізація музики соло для духових інструментів у XX - початку XXI століть закономірно формує питання щодо іï специфіки у попередній період, зокрема XIX сторіччя. Сучасним виконавцям, а також i викладачам, що звертаються до композицій інструментального соло, конче необхідно усвідомлювати цілісність історично-еволюційного процесу художньо-одноосібної духової концертної практики, розуміти на основі іï прогресії самобутні, ключові риси творчого процесу соло, оскільки усвідомлення специфіки духового одноосібного виконавства у різні культурноісторичні періоди формує максимально якісний рівень відтворення художнього змісту творів означеного виду музикування, безумовно, у відповідності до певної епохи.

Огляд літератури. Романтизм - найбільш досліджуваний період в історії духового академічного музично-виконавського мистецтва. Фундаментальні науково-дослідницькі праці В. Апатського [1; 2], Ю. Усова [9], С. Левіна [8], В. Качмарчика $[5 ; 6 ; 7]$, А. Карпяка $[3 ; 4]$ та інших вчених містять чимало інформації відносно духового соло. Та ії значення зумовлюється, переважно, грунтовним фактологічним характером (дані щодо написання творів, виконання одноосібних духових композицій, їх сценічно-творча доля тощо). На жаль, розгляд питань стосовно 
своєрідності еволюціонування індивідуальної духової практики соло, іiі виняткової самобутності відносно певного культурноісторичного періоду, наголосимо, відсутній.

Мета статті - визначення низки причин, мотивів щодо наслідків зменшення концертно-творчої активності, мистецького функціонування духового соло у сфері академічного інструментального виконавства періоду музичного романтизму.

Об'сктом дослідження постає академічне музичноінструментальне мистецтво епохи романтизму, а предметом специфічні фактори окресленої доби, які мали доленосне значення для духового академічного соло в європейській музичній культурі означеного періоду.

Виклад основного матеріалу. Еволюція сольного інструментального концерту з активізацією протиставлення соліста й оркестру та, наголосимо, стрімкий розвиток ансамблевого й оркестрового виконавства наприкінці XVIII - початку XIX століть витісняють одноосібний, творчо-індивідуальний виконавський процес, художньо довершений акт персонального інструментального творення, зокрема у лоні духового академічного музично-виконавського мистецтва.

Відносно використання духового професійного інструментарію у XIX столітті В. Апатський зазначає: „Пішовши на другий план як інструменти, що концертують, духові продовжували активно еволюціонувати в оркестрі. Саме оркестр в епоху романтизму стає основною сферою їх застосування. Й тут у них спостерігався такий ріст, який багато в чому компенсував поразку, отриману ними на сольній концертній естраді. Примат інструментальної музики у музичній естетиці романтизму висуває оркестр ХІХ століття на провідні ролі. У Свропі виникають нові першокласні оркестрові колективи" $[1,236]$.

Визначну роль у становленні європейської оркестрової культури відіграла поява й міських інструментальних зібрань у найбільших європейських містах тих часів. Велике розповсюдження отримують духові інструменти i у військовій музиці. Армійські оркестри були невіддільною частиною військових парадів, певних церемоніалів тощо. Колективне звучання духових інструментів на відкритому повітрі ставало невід'ємним елементом як знакових суспільно-політичних подій, 
так і обов'язковою мистецькою традицією будь-яких численних творчих заходів.

Підкреслимо, що вагоме значення у розвитку оркестрового виконавства часів романтизму належало саме жанру духової музики. Стрімка популяризація духових оркестрів у багатьох країнах Свропи відбувається внаслідок подій, що мали знакові звершення під час Французької буржуазної революції 1789 року. „Духові інструменти Французької революції означили велику прогресивну роль у розвитку європейського духового виконавства. 3 одного боку, за прикладом Франції, і в інших країнах Європи почали створюватись великі духові оркестрові колективи, суспільне значення яких складно переоцінити. 3 іншого боку, звучання духових оркестрів революційного Парижа розширило оркестровий стиль багатьох найвідоміших симфоністів XIX століття Бетховена, Берліоза та інших" [1, 237].

Спільним музикуванням позначалась i тогочасна побутова культура. Саме невеликі за кількістю музикантів колективи швидко створювались та мали неабияку мобільність у представленні будьяких музичних композицій різних жанрів.

Але ж, наголосимо, не можна одностайно стверджувати про абсолютне зникнення духового одноосібного художньодосконалого музикування з європейської інструментально-творчої палітри романтизму. Адже у такому випадку неможливо було б і сподіватись, як вже зазначалось вище, на розквіт духового соло у XX - на початку XXI століттях.

Свідченням функціонування сценічно-індивідуальної духової практики соло тих часів постає одна 3 небагатьох композицій, а саме Рондо-капричіозо для флейти соло німецького композитора чеського походження, скрипаля-віртуоза, викладача Антона Стаміца (1753 - 1820).

Будучи продовжувачем виконавських традицій Мангеймської симфонічної школи, А. Стаміц на початку творчої кар'єри був знаним скрипалем уславленого мангеймського оркестру. У молодому віці син Яна Стаміца вирушає до Парижа, де його творча діяльність зосереджується у декількох напрямах, а саме сольному, оркестровому виконавстві та педагогічній діяльності (серед найбільш відомих учнів А. Стаміца скрипаль-віртуоз та композитор Рудольф Крейцер). 
Якраз у такій творчій насиченості, поряд з великою кількістю власних, яскраво самобутніх композицій для струнно-смичкових інструментів, народжується, приблизно у період початку XIX століття, твір для флейти соло Рондо-капричіозо.

Мелодичну основу твору становить тема-рефрен, яка має три проведення й контрастує двом епізодам. Яскраво виражений танцювальний характер музики відтворюється надзвичайною рельєфністю мелодичної лінії, що досягається комбінованим штрихом стаккато й два легато, треллю з форшлагом на другій долі такту, а також контрастною динамікою (різка переміна гучності звука). Деталізовано прозора тема рефрену характеризується класичною стрункістю, вишуканістю та довершеністю зображення щонайменших елементів музичної тканини.

Подібні один одному перший і другий епізоди будуються за принципом контрасту відносно рефрену. Їх романтичну експресію складають стрімкі висхідні та низхідні пасажі шістнадцятими у різних динамічних типах, а саме хвилеподібному, контрастному, поступово зростаючому (терасоподібному) та навпаки, типі, нівелюючому гучність звучання інструмента.

У цілому означений контраст підкреслює граціозність, вишукану елегантність, i, насамперед, примхливість, нестабільність чуттєво-емоційної сфери означеного твору, яка у загальному сприйнятті надзвичайно влучно відповідає імпровізаційному характерові та мінливо-грайливій художньо-образній змістовності усієї композиції.

Цілком імовірно, що флейтове Рондо-капричіозо А. Стаміца було написане для одного з паризьких флейтистів-аматорів, сольна, сценічно-одноосібна практика яких була дуже популярною на початку XIX століття.

Про неабияку увагу композитора до духових інструментів свідчить факт написання А. Стаміцем сольного концерту для флейти, а також для гобоя у супроводі оркестру, що вкотре засвідчує обізнаність композитора у духовому інструментарії та, знову таки, вказує на наявність багатогранних творчих взаємозв'язків 3 тогочасними музикантами-виконавцями, як професіоналами, так і аматорами.

В. Апатський, підкреслюючи переломне значення XIX століття в історії духового музично-виконавського мистецтва, 
приводить влучну думку П.І. Чайковського, висловлену в одній 3 його музично-критичних статей у 1875 році: „Був час, коли флейта, гобой, кларнет, валторна й навіть тромбон мали власних відомих представників у світі віртуозності та були рівноправними 3 трьома теперішніми владиками (рояль, скрипка, віолончель). Ці часи від нас далеко" [1, 235].

Мистецтвознавець П. Юргенсон, досліджуючи історію виконавства на гобої, відзначає думку відомого американського музикознавця Дж. Маркса: „Велика традиція сольного виконавства на флейті, гобої та фаготі повністю вмерла у XIX столітті..., а з нею й мистецтво урівноважувати фразу й по різному здійснювати виконання цілісного витвору мистецтва. Замість цього отримувала розвиток мозаїчна техніка фразування, яка дозволяла виконавцю видобувати можливо більше з невеликих фрагментів фраз, а саме те філігранне мистецтво, яке дозволяє йому сяяти в оркестрі, але яке стає безплідним, коли воно пристосовується до сольного виконавства" [10, 65].

Серед найбільш імовірних причин такого занепаду сольного виконавства, зокрема духового сценічно-одноосібного музикування (духове соло), постає тогочасна реальність технологічноконструкційного стану тодішнього інструментарію. Порівняно зі струнно-смичковими, -щипковими, ударно-клавішними інструментами тих часів, духове інструменто-будівництво було ще на доволі примітивному рівні. При цьому духова конструкційна „революція” у 1840-х роках, яка мала колосальне значення для розвитку виразових можливостей як дерев'яних, так i мідних духових академічних інструментів, далеко не одразу зазнала схвальних апробацій та позитивних відгуків 3 боку провідних виконавців і композиторів тих часів.

Дослідник німецького флейтового виконавства періоду XVIII - XIX століть В. Качмарчик стосовно механіко-акустичних удосконалень флейти відомим німецьким інструментальним майстром, флейтистом і композитором Теобальдом Бьомом (1794 1881) зазначає наступне: „Незважаючи на приголомшливі переваги, новий інструмент був сприйнятий основною масою виконавців без особливого ентузіазму" [5, 227].

Вагомий науково-дослідницький інтерес утворюють Каприси для флейти соло Т.Бьома, які мають яскраво виражений 
інструктивний характер і постають опосередкованим свідченням акустично-конструкційних звершень видатного інструментального майстра XIX століття.

Зникнення уваги до одноосібного духового художньодовершеного акту творчості також пов'язане 3 утвердженням та стрімким розповсюдженням гомофонно-гармонічного оркестру. В ньому духові інструменти отримують нові функціональні ознаки, які найбільш яскраво виявляються в акордовому, колористичному, басовому, мелодичному призначенні 3 їх, наголосимо, новою характерологічною рисою мозаїчного використання, при застосуванні так званого латочного принципу побудови оркестрового звучання. Безперечно, таке розуміння духової виконавської специфіки унеможливлювало розвиток сольного сценічно-індивідуального музикування на духових академічних інструментах.

Та, цілком очевидно, що магістрально-вирішальне значення у тимчасовому виконавсько-творчому спустошенні духового соло мала естетика романтизму. Емоційна хвиля палких почуттів, великих пристрастей потребувала, безумовно, й відповідно нових засобів виразності. „Романтизм не сповна задовольняло спокійне, дещо споглядальне звучання дерев'яних духових інструментів, їх порівняно невеликий звук та обмежений динамічний діапазон. „Нудними трубками” іменував їх на концертній естраді австрійський музикознавець та критик Едуард Ганслік (1825 1904). Що стосується труб і валторн, то вони мали великі динамічні можливості. Але ці інструменти на початку століття залишались натуральними, а перші хроматичні труби та валторни були далекими від досконалості. Чудовий та достатньо досконалий вже у той час тромбон, як i в усі часи, вочевидь недооцінювався композиторами XIX століття. ... витримати на концертній естраді конкуренцію 3 фортепіано, скрипкою та віолончеллю духові інструменти вже були не в змозі" [1, 235-236].

Висновки. Динаміка сценічно-одноосібного художнього виконавства на духових академічних інструментах у період музичного романтизму позначається вагомим зменшенням індивідуальної духової практики соло. У низці найбільш вагомих мотивів окресленого явища видзначимо. 
Однією з причин зменшення творчої активності духового соло у сфері академічного музично-виконавського мистецтва в часи романтизму постає його наближення до царини аматорського музикування. Поціновувачі духової виконавської практики, зокрема флейтисти-аматори, як правило, не вдавались до вирішення питань щодо фортепіанного, ансамблевого супроводу тієї чи іншої композиції. Відтак, попит породжував пропозиції, представлені зокрема творчістю тогочасних професійних композиторів (А. Стаміц Рондо-капричіозо для флейти соло).

Процес опанування технікою гри на духових академічних інструментах у представників когорти музикантів-аматорів зумовлювався появою також і композицій яскраво вираженого інструктивно-технічного характеру (Т. Бьом Каприси для флейти соло). Саме такі твори зменшували можливість концертно-творчого утвердження духового соло на художній сцені XIX століття.

Послаблена активність духової індивідуальної практики соло у період романтизму $є$ наслідком і суттєвого конструкційного відставання духового академічного інструментарію від інших представників сфери професійного інструментального музикування, зокрема струнно-смичкових інструментів та, безперечно, фортепіано.

Та найголовнішою причиною зменшеного функціонування духової сценічно-одноосібної творчості у лоні професійної музично-інструментальної практики часів романтизму $\epsilon$ надзвичайно масштабний та водночас максимально високий рівень ансамблево-оркестрового виконавства, в якому духові академічні інструменти мали першорядне художнє, естетико-оновлююче значення.

Перспективи дослідження окресленої тематики визначаються проведенням грунтовного виконавського аналізу композицій духового соло означеного часу та здійсненням їх порівняльної характеристики 3 подібними творами соло, написаними в інші культурно-історичні періоди.

\section{Список використаних джерел і література:}

1. Апатский В.Н. История духового музыкально-исполнительского искусства: учебное пособие. Киев: Задруга, 2010. 320 с. 
2. Апатский В.Н. Актуальные проблемы духового музыкальноисполнительского искусства. Киев: Задруга, 2013. 588 с.

3. Карпяк А.Я. Концепційні засади художнього мислення сучасного флейтиста: монографія. Львів: Наукове товариство ім. Т.Г. Шевченка, 2013. $378 \mathrm{c.}$

4. Карпяк А.Я. Жанр флейтового концерту у творчості австрійських та італійських композиторів - сучасників В.А. Моцарта // Історія становлення та перспективи розвитку духової музики в контексті національної культури України та зарубіжжя: зб. наук. ст. Рівне: Волинські обереги, 2016. Вип. 8. C. 8-14.

5. Качмарчик В.П. Реформа Т. Бёма (к проблеме исследования механикоакустической системы флейты) // Музичне мистецтво: зб. наук. ст. Донецьк: Юго-Восток, 2004. Вип. 4. С. 218-227.

6. Качмарчик В.П. К вопросу сравнительного анализа модификаций флейты Т. Бёма // Музичне мистецтво: зб. наук. ст. Донецьк: Юго-Восток, 2005. Вип. 5. С. 218-231.

7. Качмарчик В.П. Немецкое флейтовое искусство XVIII - XIX вв.: монография. - Донецк: Юго-Восток, 2008. 311 с.

8. Левин С. Духовые инструменты в истории музыкальной культуры. Ленинград: Музыка, 1983. Ч. ІІ. 192 с.

9. Усов Ю. История зарубежного исполнительства на духовых инструментах. Москва: Музыка, 1989. 207 с.

10. Юргенсон П.Б. Гобой. Москва: Музыка, 1973. 72 с.

\section{References:}

1. Apatskij, V.N. (2010). History of wind musical performance art. Kiev: Zadruga [in Russian].

2. Apatskij, V.N. (2013). Actual problems of wind musical performance art. Kiev: Zadruga [in Russian].

3. Karpyak, A.Ya. (2013). Conceptual foundations of artistic thinking of modern flutist. L`viv: Naukove tovary`stvo im. T.G. Shevchenka [in Ukrainian].

4. Karpyak, A.Ya. (2016). The genre of the flute concert in the works of Austrian and Italian composers-contemporaries V.A. Mozart. Istoriya stanovlennya ta perspekty`vy` rozvy`tku duxovoyi muzy`ky` v konteksti nacional noyi kul tury Ukrayiny` ta zarubizhzhya, 8-14 [in Ukrainian].

5. Kachmarchik, V.P. (2004). The reform of T. Böhm (to the problem of studying the mechanical-acoustic flute system). Muzy`chne my`stecztvo, 218-227 [in Russian].

6. Kachmarchik, V.P. (2005). To the question of the comparative analysis of flute modifications by T. Böhm. Muzy`chne my`stecztvo, 218-231 [in Russian]. 
7. Kachmarchik, V.P. (2008). German flute art of the XVIII - XIX centuries. Doneck: Jugo-Vostok [in Russian].

8. Levin, S. (1983). Wind instruments in the history of musical culture. Leningrad: Muzyka [in Russian].

9. Usov, Ju. (1989). The history of foreign performance on wind instruments. Moskva: Muzyka [in Russian].

10. Jurgenson, P.B. (1973). Oboe. Moskva: Muzyka [in Russian].

УДК 782.3

DOI $10.15421 / 221811$

Shchitova Svitlana, Ph.D., Associate Professor, Professor and Head of ,History and Theory of Music” chair of M. Glinka Dnipropetrovsk Academy of music тел. (093) 151 - 99 - 81 e-mail: shchitova@i.ua

Savoniuk Hanna, Master of ,History and Theory of Music” chair of M. Glinka Dnipropetrovsk Academy of Music тел. (096) 386 - 09 - 09 e-mail: annasavonyuk@gmail.com

\section{SCRIPTURE - SOURCE OF COMPOSER'S INSPIRATION (to the 500year of Reformation)}

The aim of this article is retracing stage-by-stage development of passions and to argue actuality of genre on the modern stage, defining text biblical basis as invariable and significance. Bible became an uniting factor for all times, for believers of confessions and creations of different forms and genres, among that liturgies, masses, spiritual concerts, passions. The genre of passions has centuries-old history. The most ancient reminiscence about passions are related yet to the rituals of resurrection of Egyptian God Osiris. In the article the value of activity of M. Luther reveals not only for forming of new church confession; his musical reforms, that became the important stage in development of many genres are retraced too, including passions. Methodology of 